\title{
According to the Formal and Presumptive Business Documents
}

\section{Mohammad Bahmani}

\author{
Ph.D. of Law privacy of Beheshti University
}

Asadolah Ghasri

MA in Law privacy of Islamic Azad University. azarbaijan science and research branch

\author{
Doi:10.5901/mjss.2016.v7n3s2p179
}

\begin{abstract}
Check and promissory notes and bills of exchange, because of the departure from the provisions defined in Article 1287 BC, are not considered an official document, though, they are issued by the authorities. Issuing check law on which it enters into force in rows documents, just for being in force, is an official document, otherwise, as long as the check has not the above article conditions, is not an official document. Among the commercial documentation, development of modernism has given a special credit in the commercial documents to the traders' commercial offices. The offices are suitable means for controlling computing organs and criminal penalties by relevant agencies as well. However, in some cases, these offices can take credit in an official document and this is referable (Civil Code, Article 1297 and the Commercial Code, Article 14). In this regard, given the importance of form in Iran trade law and presumption associated with that, we study briefly of form in the commercial documents and the legal presumption position in Iran Business Law framework.
\end{abstract}

Keywords: commercial paper, promissory notes, Formalism, the Legal presumption, commercial law

\section{Introduction}

Today, few people are not associated with business documents, so that in addition to businesspersons, ordinary people also uses these documents and perhaps because of the advantages that these documents have. However, commercial papers are inseparable part of daily transactions, and little by little, the use of these documents is extended to the point that, people are reluctant to carry money with them. Commercial documents, the most important of which is Check and promissory notes and bills of exchange, according to their application, are in circulation between the merchants and the people. These documents are transmitted in different ways, one of the most famous and most convenient ways of these documents transferring is through endorsements, meaning that whoever is the owner of the business document or have permission from the owner of the business document, could transfer it with a sign to anyone who knows the right.

The importance of business documents and its history in the Iranian trade rights has created a necessity to bring about formalism in the commercial documentation.

In the new rights, the structural function or form manufacturer, can be seen in the commercial documents, due to the fact that commercial documents are single, means that, they are independent of the cause of their issue, so that they have flaws, such as a mistake or duress and misrepresentation that are the will defect and according to the general rules of contracts, they cause invalidity or ineffectiveness or lack of necessary in legal action, in return the owner in good faith of this document may not be invoked. Thus, in the commercial documentation, the appearance of the document will have superiority on the actual determination of the real issuer, it can be said that legal relations cause by such documents is based on the rights of such documents is based on their formal face and in a sense, the visible appearance of the document is the right Producer (Ghasemi, 2009).

On the other hand, "as opposed to civil rights, alleged in business affairs id simple, because any reason, such as business offices, correspondence, invoices, witnesses and presumptions will be accepted in court and does not need the evidence to prove contracts will be the function of documents special procedures in civil rights, such as the requirement to write reciprocal agreements in office real estate, etc. However, some documents in the trading rules such as securities are based on a specific form that non-compliance with them will invalidate the document. In this regard, promissory notes, bills of exchange, and check are ordinary documents that the legislator has imposed certain rules to facilitate in the receipt of their funds. Business documents are documents that are exchanged between traders in daily exchange. However, in terms of trading law, commercial documents are documents that the trading law has named them and put 
them under certain circumstances. Business documents that Iran Trade Law has named them as follows: "bills of exchange, promissory notes, and check and commercial offices". The first three documents have benefits of trade and are under special rules that have advantages over other types of documents. Their benefits are: firstly, they are the funds transfer tool. Secondly, they are credit tool. Thirdly, they used instead of cash (Erfani, 2008, p. 47).

\section{Define the Commercial Documentation}

The document has great value as a written reason, in our time, in such a way that, many contractual guarantees in social relationships, is done through the document and sign. Its impact was such that the document has been located in the first row of claim's proof evidences. The reason of this importance and great value would be searched in a few matters:

A) The risk of confusion is low in the document because usually before a claim can be considered, it is adjusted, so regulators provide it in peace of mind and in favor of it.

B) In the document, contrary to the evidence, such as testimony, the possibility of neglect cannot be concluded, because, the witness may forget what he has seen, after a while, his accuracy in recalling the details will be reduced while in the document, there will not this problem.

C) Document is gastric reason and is regulated before lawsuit, while other claim's proof evidences are not the same and therefore people prefer to manner with a preventive measure, in a way that, if in the future they will be at lawsuit side, at that time, they have not a problem for providing a reason and from the first, they have a solid evidence in hand (Education Department of the Judiciary, 2009).

Iranian Civil Code, in Article 1286, is divided the document into two kinds of official and ordinary and in Article 1287, in defining document provides: " Documents, that are regulated in the Department of Real Estate Registration and Notary public offices, or in for officials, within their competence of the legal regulations, are official, "but without defining the normal document, in Article 1289 provides:" Apart from the documents referred to in Article 1287, other documents are normal (Emami, 1996).

Legislator, in business law, has not mentioned the business documents, but in the chapter four, it refers to three commercial documents only, these documents include bills of exchange, promissory notes and check. There are other documents that are called commercial document, but they also like the three mentioned documents, titled "commercial documents" are not used in law, only in the works of writers and commentators of trading rule, this title can be seen (Skini, 2005).

The purpose of the commercial documentation is compliance the provisions of this document with the trade rules, as it is possible, these documents will be exchanged among non-traders, but it should comply with the same regulations that have been stipulated in the Commercial Code (Ibid).

As mentioned, the commercial documentation is not limited to three documents, "the bill, Check and promissory notes", but another batch is also there that has sporadically been in business law, such as warehouse receipt, document in bearer, securities, bonds, stocks, bill and credit documents. Transaction compared to some of them, the law is considered commercial in nature, such as bills of exchange and transactions for some of them is not commercial by nature, such as promissory notes. The person who engaged in bill action, is a businessman, but one who engaged in the speculative action, his employment will not trade, but it included all the business documents, whether the trader will be a merchant or not (Ebadi, 2001).

In the definition of commercial documents, it is said that "The business documents, regardless of the overall means that they may have, they generalized all the documents that will be exchanged between traders, usually are documents and papers, which are deal able and they are reagent seeking to maturity introduction of short duration (Sotoudeh Tehrani, 2006).

As well as elsewhere, in relation to the definition of the commercial documentation, this has been narrated as "commercial documents, in a certain sense, refers to documents that are portable, they involve a certain amount of the payment order, to see or to maturity short-term and they will be payment tool instead of money, and comply with legal special rules and privileges (Akhlaghi, 1997).

In business document definition, we can note this case that, "Bill sheet is a document, with specific legal status and has, the faster transfer ability, which involves short-term demand in the interest of a holder and does not pay to work independently (Soghra, 2008).

A professor of law reads the business documents as transaction able documents, and said in its definition that, "The documents that, their signatory or signatories are committed to give financial surrender (cash, good). These documents, unlike other documents have not the proof and indicative of what happened, but in the shadow of the commercial rights, have found aspects of the issue (Langroodi Jafari, 2009). According to this feature of the commercial 
documentation, it can be concluded, in documents with demand that the origin existence in it, are contractual relations, one that the document had been issued against him, could cite due to the original copies of the contract, or void commitment between or payment of commitment topic, and stand against the expresser, but the commercial documentation expresses the amount of money that is reflected in these documents and has no relation with the commitment that led to the issuance of the document, meaning that commercial document, after the issue has become a commitment that aside from the commitment between the parties, the payment will be reflected cash in entry to force document, except in cases where the law imposes non-payment orders (eg Article 223 of the commercial Code in connection with draft form) and document holder can ask his right from signers, because they have ensured the played a commitment issue liability with their signature (Kaviani, 2010).

It seems, the role of business documents is such as money, but given the problems that the money was created, businesspersons and entrepreneurs were forced to create documents, which also plays the role of money and does not have the problems in the money, briefly, we can say, money objections were as follows:

1) Difficulties in carrying it

2) The risk of theft, according to its anonymity

3) Worn banknotes, according to the matter that no cost will be taken from people in its print

4) Time consuming to count the money

5) The possibility of Counterfeiting and consequent injury suffered to the recipient fake banknotes

6) The time impossibility of money (Kaviani, 2010)

\section{Formalism and Legal Presumption in Bill}

In Iranian trade law, rules, and formal procedures are considered for the bill so that to be distinct from other documents, and if the formalities shall not be respected, the benefits of the bill were not entitled to it (Sotoudeh, 2009).

Commercial Code in Articles 223, 225 and 226 provides regulations for the bill form, which represents the elements of form in a bill, the conditions such as the stipulated word of bill on paper and the date of writing, the name, the amount of the bill, the date of writing, location, payment of the bill, copies of the bill specification, in Article 225 refers to the importance of writing the amount of bill with letters.

Then in Article 226, it referred to the importance of a formal agreement to in Article 223, so that the absence of any conditions mentioned in the above paragraphs, will remove the bill from the bill regulations of commerce.

Also in articles, 228 and 229, any other form elements in the bill are pointing out that relate to the bill accepting the agreement (Ibid).

Sanction provisions of the bill no provisions form, referred to in Article 223 of the Commercial Code, is under the influence of bill nature, that cause the nullity of the bill, for example, it is enough that the bill has not specified location, to be declared invalid, even if for some verbs and deduced reason, from the paper of the bill, the place will be detectable and set, again the opening sentence is invalid for the bill.

These strict regulations, contained in the Commercial Code, rooted in Islamic elements of public order. In fact, the effect of the court to objections in the form of the bill, does not depend on that, read from the district and raised in the court, but if the court found the defective, its votes to the invalidity of the bill; whether due to Articles 223 and 226 of the commercial Code, the contents of the bill have a public order. In addition, nothing will ever replace Article 223 , since the importance and validity of the bill require only that document will have recognized the title that has the contents referred to in Article 223, the same contents in Article 226 that are mentioned as basic conditions (Skini, 2009).

\section{Acceptance Statistics of the Bill, by the Drawee}

In Articles 229 and 232 Q.t, referred to these criteria, we see this article.

"Every word that the drawee has written on the bill, signed or stamped is acceptable unless explicitly, the word will indicate the lack of acceptance.

If the statements of only indicating the lack of acceptance are a part of the bill, the rest of the bill amount is considered acceptable. If, the drawee signature or stamp bill without writing any statement, the bill is passed.

"It is possible; the acceptance is limited to one part of the bill, in this case, the bill holder need to complain for rest."

"The drawee, after he views the bill and writes its acceptance, he will be owed to the bill holder. The Drawee, before writing his acceptance, does not have any relationship with the owner, but as soon as he accepts, he bounds his bill to be paid homage and he obliges to do his obligation. In the Article 228 of the Commercial Code, mentioned: "The acceptance of the bill will be written, signed or stamped on the bill, with the date" but there is no prohibition in the law, to 
write the passing of the bill in a separate post. It is certain, reasonable constraints in the bill will be easy to use, transfer, and endorse of it. In the acceptance, the date should be indicated and the benefit is that, if the bill is a promise of view, the payment date will be determined. For example, a bill that is issued for 30 days, from the date of the drawee's visibility date, it must be clear, what day it is seen by the drawee, so that the date of receipt of payment will be 30 days later, otherwise (if the acceptance will be written without a date, the date of the bill will be the date of viewing). In bills that, at sight, they must be paid, the date is not significant, but (if the bill is the promise of the date to view, the acceptance date will be written with all letters). The drawee has the power to accept or decline the bill "the legislator stipulated that, the bill decline must be declared explicitly and phrases that do not mean explicitly rejection, are considered acceptable. For example, if the bill taker writes on the bill" hope blessed" and signs under that, that phrase is considered as acceptable, the only drawee's signature, without mentioning any other means is considered acceptable.

\subsection{The basis of the bill-accepting statistic, by the drawee}

Accepting the bill by the drawee, must be such that to prohibit any ambiguity and the bill holder knows his task in accepting or declining it. Therefore, due to the importance of these issues, legislation creates a statistic to avoid vague acceptance by the drawee with the conditions of Article 229 Q. that is based on the "bill acceptance", which aimed to demystify from the bill taker's acceptance and in fact, by creating this criteria, the acceptor with accepting the bill, somehow, tacitly admitting to his commitment and must accept the responsibility of paying the bill, unless, his acceptance, that is considered a confession, will be reflected in the manner, in which, he declares his inner will and the law also issued the allowance, provided that conditional acceptance of the bill, by the drawee and accepting a part of the bill, of him.

\subsection{The role of the bill-accepting statistic, by the drawee}

In the value and authority of the commercial documentation, we face with two basic principles, which are opposed to each other: one "The principle of lack of attention to problems" and the other "statistical uncertainty principle" and according to the fact that lawmakers has consider specific goals in creating statistics in mind, that by accepting the uncertainty principle, and the relativity, this category of statistics will exposure to contrast and under the rule of "Whatever the combination of a first possible placement", we should gather these two reasons, so that to respect each of them and have the best result, on the other hand, according to the "principle of unfair non-possess", if, the victim of statistic, believed to distinguish a right for himself, he could challenge this principle in the range where the rules allow, so we must consider the role and value of the statistic relative, but only in a few cases its authority will be molested.

\section{Promissory Note}

Promissory note is one of the commercial documents, that the formal requirements are important.

Article 308 of the Commercial Code provides that:

Promissory note or IOU, in addition to the signature or seal, must have the dated involves the following points:

1. The amount to be paid by all letters

2. Payee

3. The date of payment

In corporate law, in the case of promissory notes, it is not mentioned like the bill, that if one of the cases mentioned in the law are not observed, the mentioned writing will not use the benefits of promissory note, but despite this, the promissory note can use the benefits of it, that is set according to the provisions of the commercial Code and if it lacks a formal agreement, the benefits that are considered for the promissory note, will not belong to it and the privileges are the same advantages that are considered for the bill.

Most of the cases that the promissory notes are raised as a statistic, it is consistent with the bill, for this reason, the legal statistics study in this regard should be prevented.

\section{Check}

A check is other commercial documents, that its form determines the legal obligations arising from it. Article 311 of the Commercial Code, stipulates on the formal agreement of the check: "In Check, the place and date of issue shall be mentioned and signed by the issuer, the payment should not have a promise, and Article 312provides that:" A check may 
be in the bearer's account or a specific person, or to transfer, it is possible to transfer to someone else because of the Signature on its back. "

Formal conditions of the Check, however briefly, is not in the Commercial Code, they are mentioned, even in cases in which, the Commerce Act is unclear about it (indicating check word on the check) the necessity of adherence to the commercial document form is clear. Adherence to form, in the Law on issuing checks, is inevitable.

\subsection{Any legal presumption in Check}

Below any legal presumption related to check is mentioned:

\subsubsection{The employment presumption of check issuer's obligation}

The legal documentation of this presumption is a unity vote number 210, dated 03.05 .1939 , the General Board of the Supreme Court of the country, which states: "Issuing check is the employment reason of the issuer's obligation." This vote, in accordance with the legal unit article adopted in 1949 was as a rule of law and the purpose shall be binding in the court. Without the supervision of public or law board, it cannot be changed, and accordingly, the third branch of Supreme Court endorsed the view and voted, "and... whereas, the mere issuance of Check, is a proof of the issuer's obligation employment for the holder."

Since check is a transferable document and payment of it is negotiable, any opposite condition, for suspending or providing the payment of Check according to law, is such as, it is not listed, (Article 3 issuing check law). The check issuer's obligation employment principle is toward its holder.

\subsubsection{The basis of check issuer's obligation employment presumption}

Custom and usage of the community know the check issuing by the issuer, the reason for the check payment and thus his owe to him, and for this reason, the General Board of the Supreme Court, as a legislator, has formalized the custom of the community notion, and has given legal status, and knows the issuing of checks as a reason for the issuer's owing.

\subsubsection{The role of check issuer's obligation employment presumption}

According to the basis of this presumption, which is based on common law, and taking into account cases where, check issuer, will issue it for reasons other than being beholden, such as those cases where the check is issued provided or to guarantee, the legislator gives this allowance to him, that act on the contrary, to the present presumption and by providing reasons for their lack of owing, its contrary will be proven, therefore, the role of this presumption and its application is relative, and there is a possibility to prove its contrast.

\subsubsection{Check Being Evidence}

"The check issuer is a sponsor to pay the fee of the check, because the check is payable to be seen, the check location must be present at the time of issuance, this matter is anticipated in all terms and Geneva uniform law also confirms".

Articles 311 and 313 Q.t., as well as Article 13 of check issuing Law are considered as the documentation on these criteria, in this connection, the Article 311 states: "... payments should not have promised. »And Article 313 adds:" the check amount must be provided as soon as giving "and Article 13 of the check issuing law provides:" check issuing as a guarantee or funding is conditional or promised or white the Signature is prohibited. "

The place of check should be usable in issuing checks time, it means cash must be in the check issuer's account, or the bank has opened a credit for him. The place of the check cannot be drafted and documents that are given to the bank to collect data and have not yet reached their maturity unless the bills were discounted and the amount of them is intended for the check issuer's account. The place of check is primarily transmitted to the receiver with issuing the check, because the payment orders written on the check are irrevocable. The legislator has placed the Check as a means of immediate payment and alternative money so that in trading, especially commercial transactions, they play an accelerating and facilitating role. Thus, any act or thing that causes a problem or impossible to achieve this goal, prohibited, including check issuing cases as a blank, secure, and promise and conditional. For example, the check "blank", which is established and delegated with the issuer's signature, due to not mentioning the amount in it, and probably, not completing other contents and the availability of exploit in more areas, it cannot realizes and makes the 
legislature' aim. Therefore, pursuant to Article 13 of the amended Law for issuing Check 1976, issuing checks as a guarantee or financing or providing, promised or blank is declared banned and its issuer is punishable by law.

Of the articles mentioned, this statistic is obtained that the Check has not promised and is present.

\section{Conclusion}

Legal presumption and formalism are the two concepts that, in some ways they obey a unified tale, so that, it seems, legal presumptions in many cases is the same formalism, which is in the Commercial Code and other rules, it seems, the basis of both returns to the philosophy of law, and often legal requirements appears in the form, and those who obey the law, see themselves as anyone that want to respect to some forms and presumptions, while it is not, and each of these cases, characterizes the law firm from and legal requirements, which have defined sanctions, in any case, it must be said that, formalism in corporate law, in a way reflects presumptions that are used in the law in this context.

\section{References}

Akhlaghi, Behrouz (1997). commercial law 3, pamphlets undergraduate courses, faculty of law and political science at Tehran, Fall 97, Page 29

Ebadi, Mohammad Ali (2001). commercial law, The Treasure of Knowledge, published thirtieth, p. 226.

Education Department of the Judiciary (2009), a series of legal research and jurisprudential-8, the validity of documents, publications, forest, first edition, p. 26.

Emami, Seyed Hassan (1996), Civil Rights, Volume 6, bookstore Islamiyah, Seventh Edition, p. 15.

Ghasemi, Mohsen (2009), Formalism in civil rights, Tehran, pp. 37 and 38.

Kaviani, Kourosh (2010), business documents law, publication of Mizan, the Third Edition.

Langroodi Jafari, Mohammad Jafar (2009), encyclopedias Civil rights and trade publications treasure of knowledge, first edition, p 139

Sadr Zadeh Afshar, Seyed Mohsen (1991). claim's proof evidences in Iran's rights, center of Tehran University Press, p. 62

Skini, Rabia (2005), commercial law, bills of exchange, promissory notes, ..., Samt publisher, ninth edition, p. 6

Soghra Mohammad (2008), business documents, Publishing holding company publications, Second Edition, p. 22

Sotoudeh Tehrani, Hasan (2006), commercial law, publisher of Justice, vol. 3, ninth edition, p. 15.

Sotoudeh Tehrani, Hasan (2009), commercial law, Tehran, Justice. 